\title{
Interfaces, ressignificações e crítica da adaptação da literatura para o cinema
}

\section{Interfaces, resignifications and critics of adaptations from literature to cinema}

\author{
Soraya Ferreira Alves* \\ Amarílis Macedo L. L. de Anchieta ${ }^{\dagger}$ \\ Mircea Cândida Frasão ${ }^{\ddagger}$
}

\begin{abstract}
This paper aims at presenting a research held at Universidade de Brasília in 2010 and 2011 in order to verify the opinion of cinematographic critics in Brazil about adaptations from literature to film. So, eight movies were selected to take part of the corpus, all of them Brazilian ones adapted from Brazilian literature and produced between 2005 and 2010. After analyzing the adaptations we made a collection of the critics available at internet about each of them. Relevant results were achieved about how the adaptations are evaluated: based on the fidelity to the source text or if the implications and resignifications of these adaptations to the target context are observed.
\end{abstract}

Keywords: adaptation - literature - cinema - critics.

Resumo: Este artigo visa apresentar pesquisa desenvolvida entre 2010 e 2011, na Universidade de Brasília, com o objetivo de verificar a posição da crítica

\footnotetext{
Professora Doutora. Departamento de Línguas Estrangeiras e Tradução - LET. Programa de Pós-Graduação em Estudos da Tradução - POSTRAD. Universidade de Brasília - UnB. E-mail: so.ferreira@uol.com.br.

${ }^{\dagger}$ Mestranda do Programa de Pós-Graduação em Estudos da Tradução - POSTRAD. Universidade de Brasília - UnB. E- mail: amarilisanchieta@gmail.com.

‡ Graduada pelo Departamento de Línguas Estrangeiras e Tradução - LET. Universidade de Brasília - UnB. E-mail: mircea.letras@gmail.com.
} 
cinematográfica vigente no Brasil no tocante às adaptações da literatura para o cinema. Para tanto, foram selecionados para o corpus oito filmes, todos brasileiros e adaptados de obras literárias também brasileiras, e que foram produzidos entre 2005 e 2010. Após as análises das adaptações, foi feito o levantamento das críticas disponíveis na internet sobre cada um deles. Ao final, após a análise das críticas, chegamos a resultados relevantes sobre como as adaptações são avaliadas: se com base no conceito de fidelidade ao texto literário de partida ou se são observadas as ressignificações e implicações dessas adaptações ao contexto de chegada.

Palavras-chave: adaptação - literatura - cinema - crítica. 


\section{Introdução}

Durante os anos de 2010 e 2011, foi desenvolvida, por estas autoras, pesquisa na Universidade de Brasília que detinha como objetivo principal a verificação da posição da crítica cinematográfica vigente no Brasil no tocante às adaptações da literatura para o cinema, pertencentes a um corpus previamente selecionado. Pretendeu-se, com isso, propor uma pesquisa que trouxesse subsídios para o entendimento de como as adaptações são avaliadas: se com base no conceito de fidelidade ao texto literário de partida ou se são observadas as ressignificações e implicações dessas adaptações ao contexto de chegada.

Nossa inquietação surgiu após o estudo de vários trabalhos sobre adaptações da literatura para o cinema e a constante afirmação de que a premissa principal da crítica, e de espectadores em geral, seria a fidelidade à obra de partida.

Dessa forma, pensamos em uma metodologia que pudesse dar suporte à nossa verificação e que nossa pesquisa pudesse trazer resultados que contribuíssem com novas abordagens para a análise crítica na área estudada.

Foram selecionados oito filmes, todos brasileiros e adaptados de obras literárias também brasileiras, e que foram produzidos entre 2005 e 2010, período em que as críticas ainda pudessem estar disponíveis.

Foram feitas, então, análises de todas as adaptações por nosso grupo de estudos ${ }^{1}$ e, em seguida, levantamento das críticas sobre cada uma delas. 0 meio que escolhemos para captar as críticas foi a internet. Ao final, após a análise destas, chegamos a resultados relevantes que serão demonstrados a seguir.

\footnotetext{
${ }^{1} \mathrm{O}$ grupo de estudos contou com a colaboração dos alunos Juliana Walczuk e Edison Oliveira.
} 
Primeiramente, contudo, discutiremos o conceito de adaptação sob a ótica de diferentes autores que nos guiaram em nosso entendimento sobre tal, bem como as possíveis implicações decorrentes dessa prática.

\section{O conceito: discussões e aplicações}

A evolução tecnológica vivenciada nos dias atuais faz com que os meios de comunicação tenham de estar em constante processo de ressignificação. Com isso, reflexões e análises sobre as teorias e práticas da tradução também se tornaram cada vez mais imprescindíveis. Nesse sentido, CATRYSSE (1997) afirma que novos meios de comunicação trazem novos meios de processar mensagens e de traduzir, e, segundo Stuart HALL (2003), a tradução é produto de cruzamentos e misturas culturais que são transportados pelo mundo. Sob essa ótica, a tradução não se restringe à prática interlingual, na qual um texto verbal em uma determinada língua é traduzido para outra língua; ele é também uma série de operações intersemióticas, nas quais um texto pertencente a um sistema de signos (verbal, visual, sonoro, etc.) é traduzido para outro sistema de signos, como é definido por PLAZA (1987). Nesse sentido, adotamos o termo adaptação como sinônimo de tradução, ou, mais especificamente no nosso caso, de tradução intersemiótica.

$O$ conceito de adaptação tem sido amplamente discutido nos estudos de tradução. A Routledge Encyclopedia of Translation Studies (BAKER, 2005, p.5) define dois tipos de adaptação: a local e a global. A adaptação local restringese a partes isoladas do texto-fonte e não engloba o produto da tradução como um todo. Pode ocorrer tanto devido à falta de equivalentes lexicais na língua de chegada como à não existência, na cultura de chegada, de um contexto cultural abordado no texto-fonte. 
Como explicam CINTRÃo e ZAVAGLIA (2007, p.1), "Esse tipo de adaptação é uma técnica localizada, motivada por fatores internos ao texto fonte, que o tradutor pode aplicar a uma unidade de tradução que envolve encontros e assimetrias entre língua e cultura-fonte vs. língua e cultura-meta."

Já a adaptação global abrange o texto-fonte como um todo, reformulando-o de acordo com fatores externos a ele e operando mudanças profundas em seu conjunto (BAKER, 2005, p. 5). Tem-se como exemplo a própria mudança de gênero textual (como a literatura para o cinema) ou a mudança do público-alvo (clássicos literários adaptados para o público infantil). Nesses casos, segundo Baker, a atuação do tradutor é percebida, pois ele deve intervir nos sentidos e na organização textual, o que acarreta em alterações mais profundas do texto. CINTRÃo e ZavagliA definem que a adaptação global pode ser aplicada

\begin{abstract}
... a todo um sistema de unidades do texto-fonte, o que afeta globalmente o produto final, como seria, por exemplo, a decisão de ambientar o texto traduzido num contexto familiar ao público-meta, modificando todo o cenário cultural do texto-fonte. Mas a adaptação global pode valer-se ainda de outros procedimentos, como omitir toda uma parte do texto-fonte, reduzi-lo ou sintetizá-lo consideravelmente, ou ainda reformulá-lo profundamente, de modo a manter com ele apenas vínculos no âmbito de seu núcleo semântico essencial, de estrutura de idéias ou de função". (CINTRÃO E ZAVAGLIA, 2007: 2)
\end{abstract}

Portanto, a idéia de adaptação adotada neste artigo está relacionada ao conceito de adaptação global, pois nessa passagem semiótica da literatura para o cinema, muitos signos que não estavam presentes na obra literária são criados e muitos outros presentes no original são suprimidos. Dessa forma, o texto traduzido ganha força não como cópia, não como segundo, mas como um processo de recriação, reescritura e que, segundo LEFEVERE (1992), leva em consideração aspectos como quem e porque reescreve, sob quais circunstâncias e para quem reescreve. Ainda segundo ele, leitores não profissionais cada vez menos leem literatura escrita por seus escritores, mas sim reescritas por seus reescritores. Como reescritura o autor considera 
resumos, resenhas, críticas, montagens teatrais, adaptações fílmicas, etc. Pode-se afirmar, então, que cada obra resultante de uma adaptação é algo único, com características próprias.

Uma vez que a adaptação audiovisual derivada de uma obra literária produz signos que traduzem signos dessa obra, são acrescentadas, necessariamente, marcas que não estavam presentes no livro aos novos signos criados. Essa alteração é ainda mais intensa quando se trata de dois sistemas sígnicos diferentes, ou com obras que estejam sendo traduzidas para novos contextos culturais e temporais. XAVIER (2003) explica que, no que diz respeito à adaptação da literatura para o cinema,

(...) livro e filme estão distanciados no tempo; escritor e cineasta não têm exatamente a mesma sensibilidade e perspectiva, sendo, portanto, de esperar, que a adaptação dialogue não só com o texto de origem, mas com seu próprio contexto, inclusive atualizando a pauta do livro. (XAVIER, 2003, p. 62)

Pode-se dizer que a maneira como uma adaptação se refere ao texto de partida tende a variar no decorrer do texto. Em certos momentos, esta pode se aproximar mais do texto de partida, em outros, com as inúmeras técnicas audiovisuais disponibilizadas, pode se afastar, reduzindo ou ampliando as idéias da obra literária. Como explica Robert Stam (2000), a adaptação é formada por uma rede de referências intertextuais e interferências textuais que geram transformações, em que textos originariam outros textos em um processo sem fim de reciclagem, transformação e transmutação. Ele afirma ainda que o texto fonte na adaptação pode sofrer uma série de operações distintas, como uma seleção de aspectos para fazerem parte da adaptação; uma amplificação de aspectos, o que significa dar uma ênfase maior a determinadas características da narrativa em detrimento de outras; atualização entre diferentes épocas; crítica; subversão; popularização e reculturalização. 
É exatamente tendo em vista essa adequação de linguagens, essencial para a adaptação, que esta pesquisa opta por buscar novos rumos para o estudo da adaptação da literatura para o cinema e tentar propor novas abordagens para a análise crítica dessa área.

\section{A pesquisa}

\subsection{Método}

Como mencionado acima, definiu-se que o corpus da pesquisa se restringiria a filmes brasileiros, adaptados de obras literárias também brasileiras, realizados entre 2005 e 2010, resultando no corpus a seguir:

- Quanto vale ou é por quilo? (2005), de Sérgio Bianchi. Baseado no conto Pai contra Mãe de Machado de Assis.

- A Máquina (2006), de João Falcão. Baseado na obra homônima de Adriana Falcão.

- $\quad$ Zuzu Angel (2006), de Sérgio Rezende. Baseado na obra Eu, Zuzu Angel, procuro meu filho de Virginia Valli.

- Mutum (2007), de Sandra Kogut. Baseado na obra Campo Geral de Guimarães Rosa.

- $\quad$ Estômago (2007), de Marcos Jorge. Baseado no conto Presos pelo estômago de Lusa Silvestre.

- $\quad$ O contador de histórias (2009), de Luiz Vilaça. Baseado na obra homônima infanto-juvenil de Roberto Carlos Ramos.

- Budapeste (2009), de Walter Carvalho. Baseado na obra homônima de Chico Buarque. 
- Quincas Berro D'água (2010), de Sergio Machado. Baseado na obra homônima de Jorge Amado.

A partir da delimitação do corpus, foram analisadas as obras literárias e os filmes, com o intuito de observar as estratégias adotadas nas adaptações. Em seguida, foi feito um levantamento minucioso das críticas de cinema referentes aos filmes, buscando-se verificar se estas se baseavam apenas no conceito de fidelidade ou se observavam também as ressignificações das obras fílmicas, considerando o contexto para o qual foram traduzidas.

\subsection{As adaptações}

$\mathrm{Na}$ análise das adaptações que compõem o corpus da pesquisa, cada obra foi estudada de forma particular, sendo verificados os diversos recursos utilizados em cada uma delas. Definiram-se alguns pontos relevantes que serão apresentados a seguir. Não se pretende, aqui, porém, apresentar em detalhes a análise qualitativa que foi feita de cada uma das obras, mas ressaltar alguns pontos importantes de cada uma delas a fim de demonstrar, posteriormente, nosso levantamento e posição da crítica sobre cada uma delas.

A obra Quanto vale ou é por quilo? destaca-se pela atualização do conto de Machado de Assis, Pai contra mãe (1997), utilizado-o mais como plano de fundo para uma crítica social, característica marcante do diretor Sérgio Bianchi. O conto de Machado de Assis é, então, contado de duas formas: na época da escravidão e nas relações de dominação dos dias de hoje. O diálogo estabelecido entre o conto e o filme ocorre de forma direta e visível. O conto norteia a narrativa do filme que é costurada por pequenas crônicas advindas dos autos do Arquivo Nacional do Rio de Janeiro. Tanto o conto quanto o filme constituem uma miscelânea de estilos. No conto, 
segundo BASTOS (2007), "crônica e ficção coexistem do início ao fim". Enquanto, no filme, de acordo com LusVARGHI (2006), a mídia é onisciente e onipresente, há momentos em que os personagens se comportam como se estivessem em uma entrevista. Essa característica demonstra a colagem de gêneros presente no filme, chegando a assemelhar-se aos documentários.

A reescritura do texto nos permite compreender semelhanças entre a nossa sociedade e a sociedade de um século atrás. Bianchi revela a sua posição como cineasta de crítica mordaz à burocracia, à burrice institucional, às mazelas da sociedade brasileira, pois o filme consegue retratar a hipocrisia com que Machado narra o texto, transportando-a para a hipocrisia de ONGs brasileiras, duramente criticadas. Ele atualiza a hipocrisia que permeava a sociedade na época da escravidão, que hoje se manifesta como um preconceito velado, e se configura em uma adaptação tanto literária quanto temporal.

A adaptação de $A$ máquina tem uma peculiaridade, pois a autora do livro é também roteirista e o diretor é seu parceiro em outros trabalhos; além disso, antes do cinema, a obra literária já havia sido traduzida para o teatro. Assim, há um compromisso maior com a palavra escrita, como afirma a autora do livro: "Eu escrevo 'a tarde envelheceu' e sei que o João vai encontrar um caminho. Confio e sou admiradora do trabalho dele, tenho certeza de que a frase que criei será transposta de maneira tão linda ou mais". (Adriana Falcão, em Entrevista publicada na revista Panorama Editorial - Câmara Brasileira do Livro -, ano II, $n^{\circ} 16$ ).

A poética do filme foi mantida, sobretudo, de duas maneiras: preservando a palavra em si na narração de Paulo Autran - que interpreta o protagonista mais velho - e o conjunto fortemente trabalhado de fotografia e cenografia. Dessa forma, a escrita de Adriana Falcão é traduzida em cores, luzes e entonação. A câmera, diferente do que ocorre em Mutum e Budapeste (como veremos a seguir), não apresenta como característica principal a transmissão do ponto de vista: ela transmite, principalmente, subjetividade; 
como ocorre na cena em que Antônio e Karina, protagonistas, ensaiam para uma peça fictícia, na garagem onde o primeiro trabalha, pois quase todo 0 diálogo é acompanhado com a câmera focalizando o reflexo dos dois em uma bacia d'água. Esse objeto nos remete à ideia dos espelhos, que segundo Branigan "serve para conter uma ou mais subjetividades, mas de um modo incerto e à distância dos personagens, o efeito é inquietante" (BRANIGAN, 2005: 275). Além disso, os recursos de câmera são também influenciados pelo teatro, o filme não esconde que há um público, cria-se uma atmosfera onírica, a ficção é então evidenciada.

Outro ponto relevante refere-se à ampliação de personagens e contextualização das cenas. Isso ocorreu para trazer agilidade e sustentação à dinâmica da peça cinematográfica, ou seja, são elementos necessários para um meio dinâmico e de um alcance de público maior, o que denota o compromisso com os diferentes códigos, mantém-se as expectativas de mercado sem abandonar a riqueza que a literatura traz ao cinema.

O livro Eu, Zuzu Angel, procuro meu filho (1986), no qual se baseou a obra fílmica Zuzu Angel, mescla documentos, cartas e depoimentos. Não há, portanto, um enredo sequencial, não há definições temporais claras e aponta um percurso de cerca de cinco anos da estilista. Assim, o grande desafio do filme é transformar toda a carga dramática - estritamente definida por palavras - em algo, de fato, cinematográfico. O primeiro passo é criar linearidade, entretanto, manteve-se o sentido de mistura de gêneros textuais do livro por meio de flashbacks. Segundo STAM (2000), a obra fílmica cria transformações espaço-temporais, dessa forma, a rememoração a partir de flashbacks denota a transposição dos diversos depoimentos - e idas e vindas empregados no livro. A adaptação não explora os diversos recursos imagéticos que o cinema pressupõe, nesse sentido, transmite com facilidade as duras críticas à ditadura, aproximando-se muito mais do gênero televisivo do que do cinema, em geral mais simbólico e visual, com exceção de poucas cenas, como afirma a crítica de Marcelo Hessel: 
ALVES,S.; ANCHIETA, A.; FRASÃO, M. Interfaces, ressignificações e crítica da adaptação da literatura para o cinema

O milico se aproxima do carro de Zuzu Angel, no rádio toca a fita que Chico Buarque gravou para ela. A música é Apesar de Você, clássico contra a ditadura. 0 sujeito aperta botão, bate, chuta, não consegue ejetar a fita. O carro está semidestruído, mas a música não pára. É um simbolismo óbvio? Sem dúvida. Mas é um dos raros momentos em que Zuzu Angel (2006), longa baseado em história real, se torna cinema de fato - narrado por meio das imagens, e não só das palavras. (HESSEL, 2006. Disponível em <http://www.vermelho.org.br/noticia.php?id_noticia=5900\&id_secao=11>. $[15 / 06 / 2011])$

Em Mutum a história é contada a partir da visão de Thiago (na obra literária, Miguilim). A narrativa literária é feita em terceira pessoa, mas com o ponto de vista do protagonista, com a utilização do discurso indireto livre. 0 narrador, nesse caso, utilizando-se da onisciência seletiva (FrIEDMAN, 2004), incorpora à sua voz informações sobre os sentimentos e pensamentos do personagem. Assim, a composição do enredo é diluída no entendimento do menino. A diretora Sandra Kogut, em seu filme, também privilegia o pontodevista do menino. Ao narrar a história através do olhar deste, muitas vezes as informações sobre os fatos se tornam ainda mais diluídas, pois não há a expressão do pensamento de Thiago sobre as coisas e as pessoas, mas somente os momentos e falas presenciados por ele.

A fim de incorporar a onisciência seletiva à narrativa fílmica, a posição de câmera direciona o espectador ora de forma a ver aquilo que a personagem vê, ora a ver o que o narrador conta, estabelecendo, de forma criativa, assim como Rosa, uma imbricada relação e troca de olhares. A cena inicial do filme deixa claro esse posicionamento: o quadro apresenta uma trilha e a cabeça de um cavalo, do ângulo de visão de alguém que está montado nele. Em seguida, as patas do cavalo são inseridas na paisagem e vêse, então, um homem e um menino montados no cavalo. Apresentam-se, então, tanto a visão daquele de onde parte a história e suas percepções do mundo, bem como a do narrador. Uma vez que "a representação fílmica supõe um sujeito que a contempla, e ao olho ao qual é destinado um lugar 
privilegiado" (AUMONT et al, 1995, p.33), torna-se necessário compreender a quem pertence esse olhar. Como afirma Silva,

\begin{abstract}
A transição de um ponto de vista único, no cinema dos primeiros tempos, para um ponto de vista múltiplo e articulado, representou o esforço no manejo das estruturas simbólicas a fim de criar novas possibilidades narrativas. No ponto de vista único, o espectador tende a observar a cena; no ponto de vista múltiplo, ele participa narrativamente da cena, por identificação, fluindo pelo espaço e pelo tempo, e partilhando da subjetividade dos personagens. (SILVA, 2008: $\mathrm{s} / \mathrm{p})$
\end{abstract}

Em Budapeste, a cena inicial também revela o ponto de vista por onde se verá a história. A cena começa em um túnel, não muito longo, pouco nítido. Aos poucos, a figura de um homem surge, juntamente com uma voz em off: "A primeira vez que fui parar em Budapeste graças a um pouso forçado, quando voava de Istambul a Frankfurt, com conexão para o Rio". O homem caminha em direção à câmera, a imagem fica nítida e a voz continua: "pensava que ela era cinzenta, mas não..."; a tela escurece, surge em cor cinza a palavra 'Budapeste', no mesmo movimento de se tornar mais nítida, a voz pronuncia a palavra e termina a frase "é amarela"; a fonte da palavra muda para a cor amarela. Evidencia-se assim que o ponto de vista do filme é o mesmo do narrador, e mais, esse narrador é o protagonista.

Entretanto, diferente do que ocorre em Mutum, a câmera não acompanha o campo de visão do narrador. Esse efeito pode ser explicado como forma de manutenção da metalinguagem transmitida pela obra literária, já que o livro Budapeste (2009), de Chico Buarque, trata de um ghost-writer carioca que se aventura em uma outra língua, o húngaro, "única língua que o diabo respeita" (BUARQUE, 2009, p. 6). À medida que o protagonista aprofunda seu conhecimento nesse idioma tão atraente a ele, outro mundo também é criado, pois o personagem vê-se dividido, não entre dois amores - como se supõe a princípio -, nem entre duas cidades; mas, sobretudo, entre duas línguas que passam a compor sua própria vida. Assim evidencia-se o caráter 
metalinguístico da obra, que se consolida a partir de um jogo de espelhos: as idas e vindas do escritor e os livros que ele compõe são como duplos de um mesmo objeto, ou seja, a própria literatura. Temos aí uma história que conta a si mesma. Diante disso, a tradução cinematográfica enfrenta problemas fundamentais: como tratar a questão da obra literária em outro meio sem ignorar a metalinguagem proposta no livro? E como lidar com um narrador em primeira pessoa num ambiente tão comumente associado à onisciência?

Pode-se dizer que a adaptação fílmica Budapeste apresenta um narrador autodiegético, ou seja, "a entidade responsável por uma situação ou uma atitude narrativa específica: aquela em que o narrador da história relata as suas próprias experiências como personagem central da história" (CARDOso, 2003, p. 58), o que é verificado pela narração em off e pelas situações vivenciadas. Entretanto, a posição da câmera, na maior parte do tempo em um ângulo superior ao personagem, não permite essa mesma interpretação, pois segundo Branigan "o conceito de 'olhar' implica a existência de um observador consciente de cujo ponto de vista podemos participar" (BRANIGAN, 2005, p. 253).

Ora, se não é por meio do olhar de José Costa - aquele que narra toda a sequência -, quem é esse observador consciente? Pela proposta do livro que se lê ter sido escrito por um autor diferente do autor-narrador, é possível pensar que o olhar é o do outro ghost-writer, provavelmente o Sr.., outro personagem da história. Mas estamos diante de um filme, então para sustentar a existência de um duplo, um outro olhar, o ponto de vista não pode ser outro, a não ser o do diretor. É possível entender essa duplicidade nas cenas em que mais se evidencia o caráter ambíguo da narrativa, como ocorre no último momento do filme.

Dessa forma, o longa-metragem buscou algo que sustentasse a característica metalinguística do livro, esclarecida na cena final, em que o protagonista fala para a câmera, e, na sequência, o plano se aproxima de um espelho e outra câmera se torna visível. 0 que se pretendia nesse ponto era a 
manutenção do código que se volta para ele mesmo, ponto principal da obra de partida.

As alegorias utilizadas em $O$ contador de histórias ilustram uma visão infantil, as imagens se formam a partir do imaginário de criança, com elementos próprios desse universo: cores, magia, circo. O ponto de vista então traçado compreende o que afirma BRANIGAN (2005, p. 253) "o conceito de 'olhar' implica a existência de um observador consciente de cujo ponto de vista podemos participar". Esse 'olhar' é o de um observador que mais tarde se consagrará como um contador de histórias, o próprio protagonista que percebe a realidade de outra forma, cheio de sonhos e esperanças. Nas duas primeiras páginas do seu livro, a biografia do autor aparece narrada em terceira pessoa. Nela, a trajetória de Roberto Carlos é narrada sem muitos detalhes, apresentando apenas um panorama dos obstáculos enfrentados por ele. Tomando como base essa biografia e partindo, portanto, de um universo infantil, o diretor Luiz Vilaça utilizou muitas imagens do repertório das crianças para narrar eventos que muitas vezes eram de extrema dor na vida do contador. $\mathrm{O}$ tom imaginativo e colorido aproxima as crianças ao filme, e o filme ao livro.

Fazendo referência ainda ao aspecto estrutural do livro infantil, livro e filme se aproximam. $O$ livro de Roberto Carlos vem acompanhado de um CD, em que ele demonstra sua faceta de contador de histórias ao narrar as histórias de seu livro. No filme, Roberto Carlos também é o narrador de sua própria história. Durante todo o filme, sua voz aparece em voice-over nos momentos em que há interferência do narrador na história. Essa técnica, além de aproximar o filme do aspecto de contação de histórias, faz também referência ao próprio aspecto do livro, que também é contado. Portanto, apesar de não haver relação aparente entre as histórias presentes no livro e as que são contadas no filme, é possível perceber diversas relações estruturais entre as duas obras. 
ALVES,S.; ANCHIETA, A.; FRASÃO, M. Interfaces, ressignificações e crítica da adaptação da literatura para o cinema

O filme Estômago baseou-se no conto de Lusa Silvestre Presos pelo Estômago do livro Pólvora, Gorgonzola, Alecrim (2005). O conto narra a trajetória de Nonato como cozinheiro dentro da prisão. Não fica claro no conto o motivo da prisão de Nonato, a única referência feita a isso é "Nonato com faca na mão, Nonato sem argumentos no meio de uma discussão mais acalorada, Nonato fez o que não devia”. Por conta dessa briga com faca na mão, Nonato teria sido condenado a dois anos de prisão. Esse 'vazio' deixado no conto da trajetória de Nonato antes de ser preso, deu ao diretor um grande espaço de criação. No filme, portanto, os dois momentos na vida de Nonato se desenrolam simultaneamente. No início do filme, Nonato conta a história do queijo gorgonzola. A cena é interrompida para mostrar a imagem de Nonato chegando à cidade grande.

0 tom do conto é mantido no filme, pois, em alguns momentos no conto, o narrador cita "um bom humor do destino". Tanto no filme quanto no conto, oscila-se entre o tom de comédia e as tensões típicas de um presídio, ambos permeados pelos palavrões típicos do ambiente do presídio e do subúrbio.

Apesar de ser possível perceber o mesmo tom, há uma diferença entre os personagens principais do conto e do filme. O Nonato do conto não quer mais se envolver em confusão, quer apenas cumprir sua sentença e recomeçar a vida fora da cadeia. É um rapaz quieto, recém-chegado do Ceará e que não pode ser caracterizado como um ignorante. Já no filme, há uma caracterização de Nonato como um nordestino matuto. A imagem de Nonato na maior parte do filme é de sonso, no entanto, ao final, apresenta-se um retrato vingativo de Nonato, que não apenas mata a noiva Íria e seu chefe Giovanni, como também mata o "chefe" da cela, Bujiú. Não há, portanto, um arrependimento no Nonato do filme, nem mesmo é citada a intenção dele em sair da prisão.

O filme apresenta a maior parte dos fatos narrados no conto e chega a reproduzir alguns dos diálogos e monólogos deste. Ao assistir ao filme, é 
possível acompanhar a história do queijo gorgonzola contada por Nonato lendo o conto, pois a fala é muito semelhante.

No filme, a questão temporal é muito marcante, já que dois momentos diferentes ocorrem simultaneamente. Na alternância dos momentos, há uma ruptura clara entre as cenas que são intermediadas por uma tela preta. Essa quebra da cena pode fazer referência à própria estrutura do conto, que é feito de pequenos recortes das imagens de Nonato na prisão. Lusa Silvestre divide o conto em trechos que chegam a ser até mesmo de um parágrafo. Repleto de referências diretas ao conto, o filme, portanto, aproveitou os espaços 'vazios' para criar.

Quincas Berro D'água, de Sergio Machado, baseado em A morte e a morte de Quincas Berro D'água de Jorge Amado (2008), conta a história de um funcionário público que um belo dia se aborrece com a vida em família e decide largar tudo, tornando-se, então, o rei dos bordéis e bares de Salvador. Um dia, porém, é encontrado morto e aí começa a saga de suas voltas pela cidade, levado por seus amigos. Na verdade, a saga de seu corpo morto.

A adaptação, diferentemente do romance, é calcada na comédia e na agilidade das falas e cenas. Algumas cenas do livro foram cortadas e outras acrescentadas, bem como muitas das piadas. Os créditos iniciais do filme são apresentados com uma animação que dialoga com o enredo e dá pistas sobre a história. A narração do filme é feita pelo morto, em flashback, que descreverá sua morte e depois a segunda morte, quando seu corpo desaparece no mar após a peregrinação de uma noite pelas ruas e bares da cidade.

É interessante perceber como a adaptação dialoga com o livro no sentido de explorar ao máximo o recurso de cores que se ligam ao ambiente baiano, do artesanato, das ruas, das roupas, das fitas do Senhor do Bonfim, muito presentes nas obras de Amado. A iluminação também merece destaque, pois assume um caráter teatral ao selecionar e destacar pontos em uma cena, dirigindo o olhar do espectador, o que é feito priorizando-se movimentos de câmera em outros filmes já citados. 
ALVES,S.; ANCHIETA, A.; FRASÃO, M. Interfaces, ressignificações e crítica da adaptação da literatura para o cinema

Apesar de mudar o tom da história, o filme utiliza da comédia para estabelecer a crítica à sociedade aristocrata como o faz o livro, dando ênfase à hipocrisia de valores e costumes.

A partir das análises, pode-se confirmar a afirmação de Cintrão \& Zavaglia:

... a adaptação poderia ser vista como uma operação de analogia, que trabalha com pontos de contato tênues entre duas grandezas, mais abstratos e parciais do que aqueles percebidos como necessários quando se considera a equivalência como uma operação que deveria manter invariável um sentido referencial (remissão de um significante a objetos ou estados de coisas no mundo) (CINTRÃo E ZAVAGLIA, 2007: 4).

\subsection{A crítica - análise quantitativa}

Todas as críticas foram retiradas da internet, no período de setembro de 2010 a abril de 2011, e classificadas quanto ao grau de especialização e organizadas nos seguintes grupos: críticas especializadas em cinema; especializadas em literatura; não especializadas; presentes em sites de revistas. Dessa forma, foi possível estabelecer um perfil das críticas do cinema brasileiro. Tal levantamento foi realizado em sites que trazem colunas sobre cinema, tais como Veja, Isto É, Época, etc., bem como em sites e blogs especializados, além de blogs e sites não especializados.

A fim de esquematizar nossa análise, foram confeccionadas tabelas para cada filme, que serão mostradas a seguir: 
ALVES,S.; ANCHIETA, A.; FRASÃO, M. Interfaces, ressignificações e crítica da adaptação da literatura para o cinema

\begin{tabular}{|c|c|c|c|c|c|c|c|c|c|c|}
\hline \multirow{3}{*}{$\begin{array}{c}\text { ANO DA } \\
\text { ADAPTAÇÄO }\end{array}$} & \multirow{3}{*}{$\begin{array}{l}\text { ANO DO } \\
\text { LIVRO }\end{array}$} & \multicolumn{9}{|c|}{ QUANTO VALE OU É POR QUILO? } \\
\hline & & \multirow{2}{*}{ SITES DAS CRITICAS } & \multicolumn{4}{|c|}{ TIPOS DE FONTE } & \multirow{2}{*}{ CRITICAS } & \multicolumn{3}{|c|}{ OBSERVAÇÖES } \\
\hline & & & $\begin{array}{l}\text { Sites e Blogs } \\
\text { especializados em } \\
\text { cinema }\end{array}$ & $\begin{array}{l}\text { Especializados } \\
\text { em literatura }\end{array}$ & $\begin{array}{c}\text { Näa- } \\
\text { especializados }\end{array}$ & Revistas & & $\begin{array}{l}\text { Menciona } \\
\text { adaptaçăo }\end{array}$ & $\begin{array}{c}\text { Nằ } \\
\text { menciona }\end{array}$ & $\begin{array}{l}\text { Detalhes } \\
\text { (slimNâ0) }\end{array}$ \\
\hline \multirow{17}{*}{2005} & \multirow{18}{*}{1906} & nttp://hww.comciencia.br & & & $x$ & & \multirow{17}{*}{17} & $\mathrm{X}$ & & SIM \\
\hline & & hittp://recantodasletras.uol.com.br & & & $x$ & & & & & NẪO \\
\hline & & nitp://recantodasletras. uol.com.br & & & $x$ & & & $\bar{X}$ & & NAिO \\
\hline & & nitp://lellenvicious.multiply.com & & & $x$ & & & $X$ & & NÄ0 \\
\hline & & nttp://www.overmundo.com.br & & & $x$ & & & & $X$ & \\
\hline & & nttp:-Imiltsladeia.blogspot.com & & & $x$ & & & & 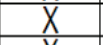 & \\
\hline & & hitp://aplauso.imprensaoficial.com.br & $\bar{x}$ & & & & & & $X$ & \\
\hline & & intp://marconegro.blogspot.com & & & $x$ & & & $X$ & & \\
\hline & & nttp://www.anhembi.br & & & $x$ & & & 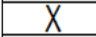 & & NAिO \\
\hline & & hitp://pt.shvoong.com & & & $x$ & & & & $X$ & \\
\hline & & hitp:///www.nocafofofo.com.br & & & $\bar{x}$ & & & $X$ & & SIM \\
\hline & & hitp://marianailis.spaces. live.com & & & $x$ & & & $x$ & & SIM \\
\hline & & nttp://seteventos.com & & & $x$ & & & & $X$ & \\
\hline & & nttp://aplauso.imprensaoficial.com.br & $x$ & & & & & & $X$ & \\
\hline & & hitp://aplauso.imprensaoficial.com.br & $x$ & & & & & & $\bar{X}$ & \\
\hline & & nttp://aplauso.imprensaoficial.com.br & $x$ & & & & & & $X$ & \\
\hline & & nttp://aplauso.imprensaoficial.com.br & $\bar{x}$ & & & & & & X & \\
\hline & & & 5 & 0 & 12 & 0 & $x$ & 8 & 9 & \\
\hline
\end{tabular}

Sobre o filme Quanto vale ou é por quilo? 17 críticas foram coletadas. Doze foram de sites não especializados e cinco de sites especializados em cinema. Entre elas, oito mencionaram o fato de se tratar de uma adaptação, e todas as que mencionaram eram críticas advindas de sites não especializados. Apenas três críticas foram além do mero fato de mencionar o texto em que foi baseado o filme e discutiram mais detalhadamente a questão da adaptação. 
ALVES,S.; ANCHIETA, A.; FRASÃO, M. Interfaces, ressignificações e crítica da adaptação da literatura para o cinema

\section{AMÁQUINA}

\begin{tabular}{|c|c|c|c|c|c|c|c|c|c|c|}
\hline \multirow{2}{*}{$\begin{array}{c}\text { ANO DA } \\
\text { ADAPTAÇAOO }\end{array}$} & \multirow{2}{*}{$\begin{array}{l}\text { ANO DO } \\
\text { LIVRO }\end{array}$} & \multirow{2}{*}{ SITES DAS CRITICAS } & \multicolumn{4}{|c|}{ TIPOS DE FONTE } & \multirow{2}{*}{ CRITICAS } & \multicolumn{3}{|c|}{ OBSERVAÇÖES } \\
\hline & & & $\begin{array}{l}\text { Sites e Blogs } \\
\text { especializados } \\
\text { em cinema }\end{array}$ & \begin{tabular}{|l} 
Especializados \\
em literatura
\end{tabular} & $\begin{array}{c}\text { Näo. } \\
\text { especializados }\end{array}$ & Revistas & & $\begin{array}{l}\text { Menciona } \\
\text { adaptaçâao }\end{array}$ & $\begin{array}{l}\text { Nắo } \\
\text { menciona }\end{array}$ & \begin{tabular}{|l} 
Detalhes \\
SIIMNNÄ0)
\end{tabular} \\
\hline \multirow{7}{*}{2006} & \multirow{7}{*}{1999} & http://hojetemcinema.wordpress.com & $x$ & & & & \multirow{7}{*}{7} & $x$ & & SIM \\
\hline & & http://pt.wikkipedia.org & & & $x$ & & & & $x$ & \\
\hline & & hittp://hww. fickr.com & & & $x$ & & & & $x$ & \\
\hline & & hitp://linema.uol.com.br & & & & $x$ & & $x$ & & NÃO \\
\hline & & http://www.jorgetadeu.com.br & & & $x$ & & & $x$ & & NÃO \\
\hline & & http://hww.cinemaemcasa.com.br & $x$ & & & & & & $x$ & \\
\hline & & hittp://www.poppycorn.com.br & $x$ & & & & & & $x$ & \\
\hline & & & 3 & 0 & 3 & 1 & $x$ & & & \\
\hline
\end{tabular}

Foram coletadas sete críticas sobre o filme $A$ máquina. Três delas eram de sites especializados em cinema, três de sites não especializados e uma de revista. Três críticas mencionaram a adaptação, sendo uma de cada categoria. Apenas uma crítica se aprofundou na questão da adaptação, a crítica do site especializado em cinema.

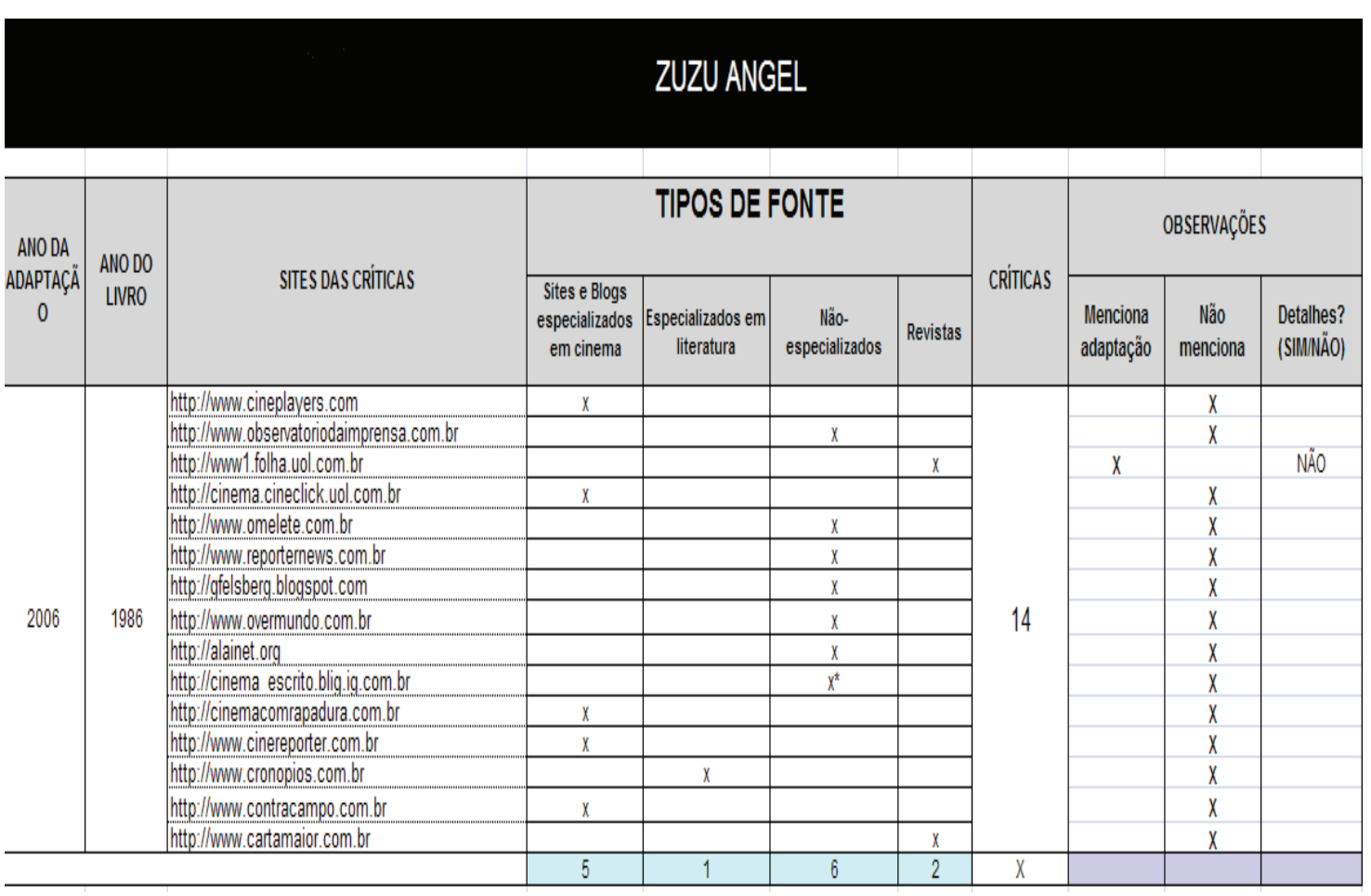


ALVES,S.; ANCHIETA, A.; FRASÃO, M. Interfaces, ressignificações e crítica da adaptação da literatura para o cinema

Quanto ao filme Zuzu Angel, foram coletadas 14 críticas. Cinco de sites especializados em cinema, uma de site especializado em literatura, seis de sites não especializados e duas de sites de revistas. Apenas uma crítica (site de revista) mencionou o fato de ser uma adaptação e, ainda assim, apenas citou a existência de uma obra de origem.

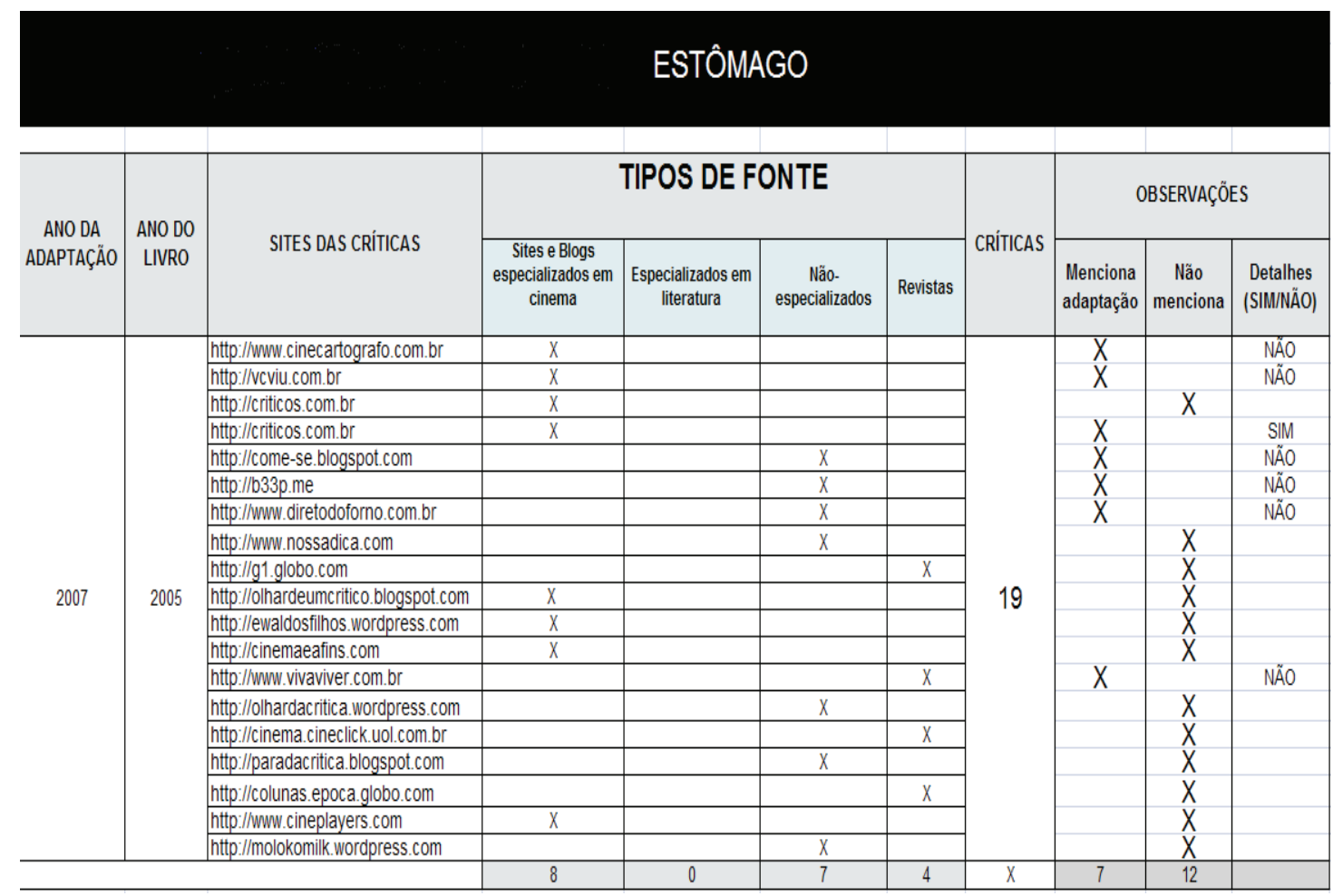

Foram coletadas 19 críticas do filme Estômago. Oito de sites especializados em cinema, sete de sites não especializados e quatro de sites de revista. Entre elas, sete mencionaram a adaptação (três dos sites especializados em cinema, três de sites não especializados e uma de site de revista). Apenas uma dessas críticas, de site especializado em cinema, acrescentou mais detalhes relacionados à adaptação. 
ALVES,S.; ANCHIETA, A.; FRASÃO, M. Interfaces, ressignificações e crítica da adaptação da literatura para o cinema

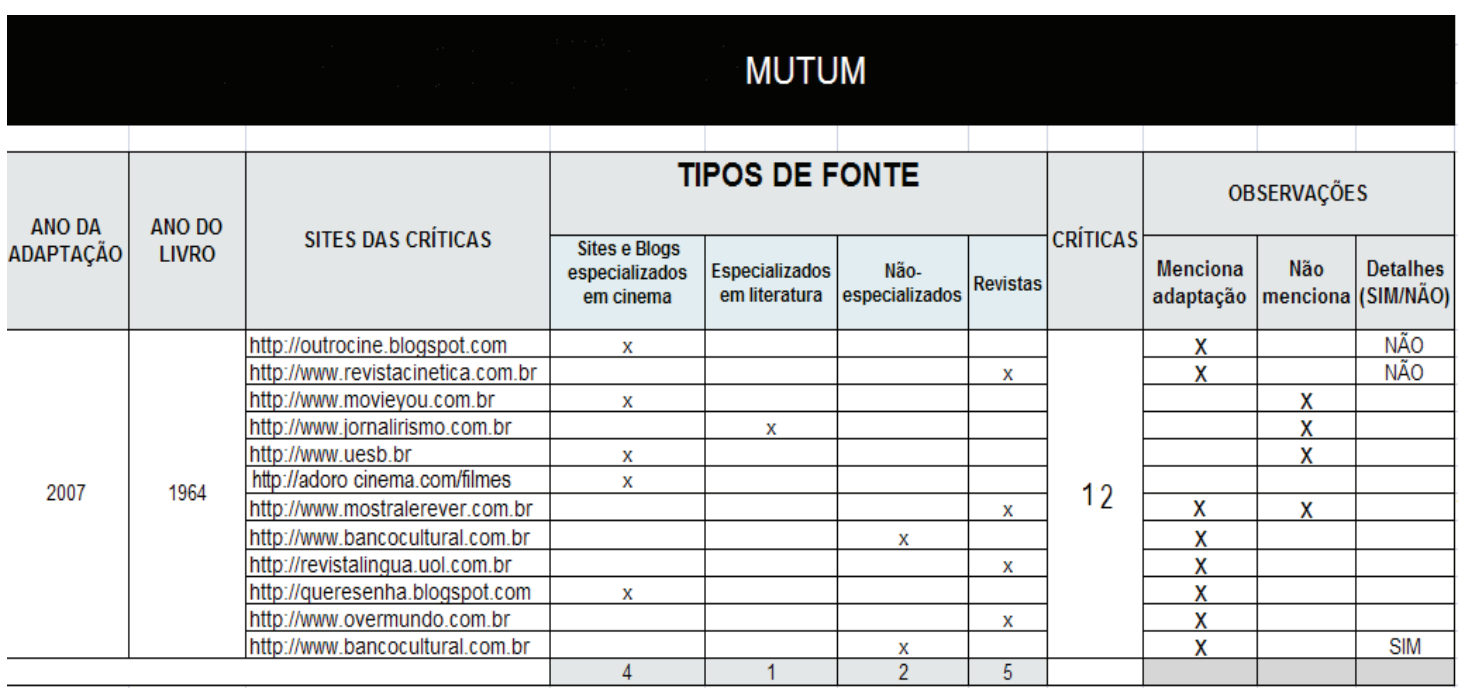

Foram coletadas 12 críticas do filme Mutum, sendo quatro de sites especializados em cinema, uma de site especializado em literatura, duas de sites não especializados e cinco de sites de revistas. Oito delas mencionaram a adaptação, duas de sites especializados em cinema, duas de sites não especializados e quatro de sites de revistas. Duas delas mencionaram a adaptação detalhadamente, uma de site não especializado e uma de site de revista.

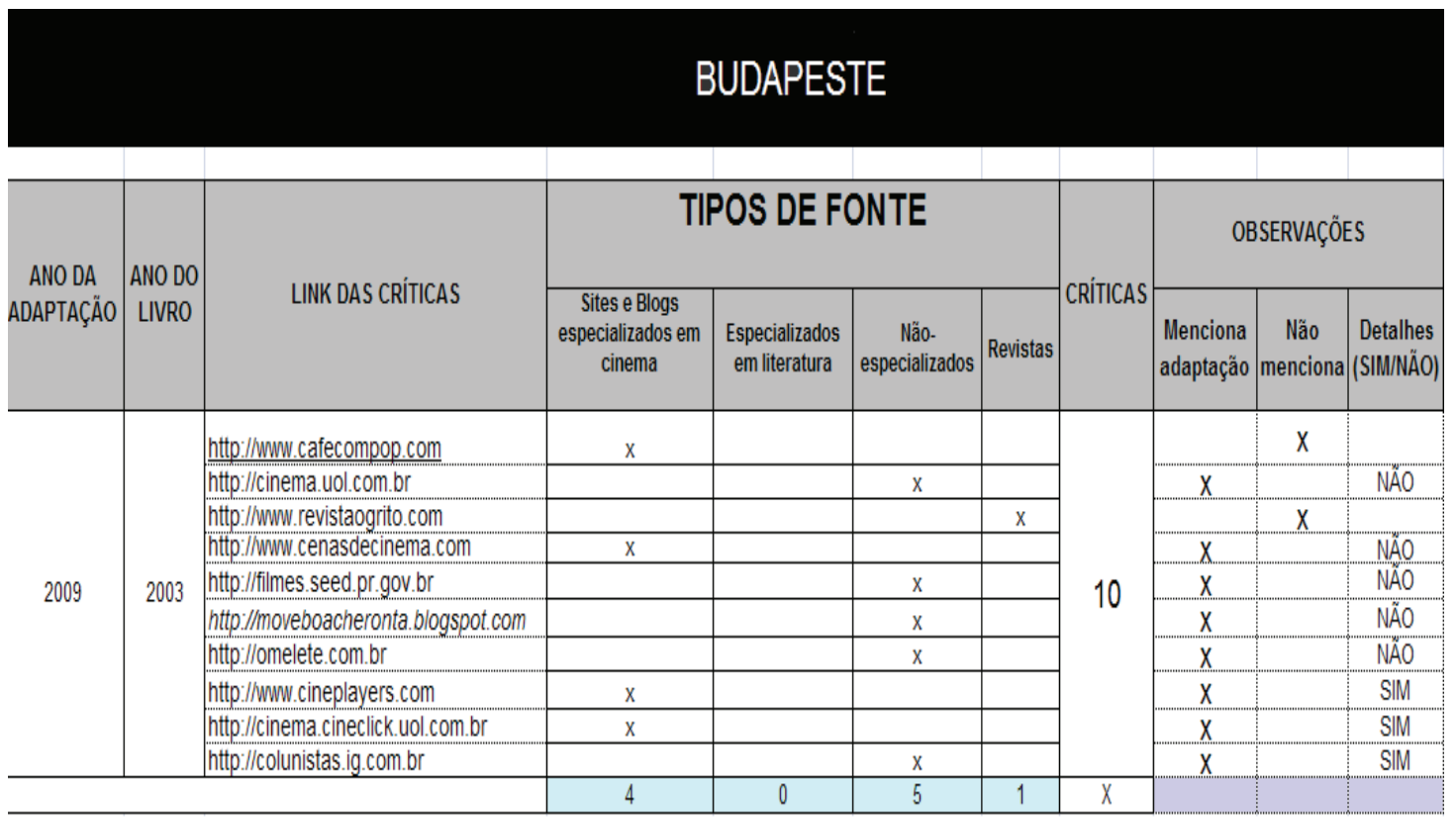


ALVES,S.; ANCHIETA, A.; FRASÃO, M. Interfaces, ressignificações e crítica da adaptação da literatura para o cinema

Do filme Budapeste, foram coletadas dez críticas. Quatro delas de sites especializados em cinema, cinco de sites não especializados e uma de site de revista. Entre elas, oito mencionaram a adaptação (três de sites especializados em cinema e cinco de sites não especializados). Nesse caso, três críticas examinaram a adaptação com mais detalhes (duas de sites especializados em cinema e uma de site não especializado).

\section{O CONTADOR DE HISTÓRIAS}

\begin{tabular}{|c|c|c|c|c|c|c|c|c|c|c|}
\hline \multirow{2}{*}{$\begin{array}{c}\text { ANOOA } \\
\text { ADAPTAÇĀO }\end{array}$} & \multirow{2}{*}{$\begin{array}{l}\text { ANODO } \\
\text { LINRO }\end{array}$} & \multirow{2}{*}{ SITES DAS CRITICAS } & \multicolumn{4}{|c|}{ TIPOS DE FONTE } & \multirow{2}{*}{ CRITICAS } & \multicolumn{3}{|c|}{ OBSERVAÇÖES } \\
\hline & & & $\begin{array}{c}\text { Sites e Blogs } \\
\text { especializas } \\
\text { em cinema }\end{array}$ & \begin{tabular}{|c|c} 
Especializados em \\
literaturara
\end{tabular} & \begin{tabular}{|c|} 
Năa. \\
especializados
\end{tabular} & Revistas & & \begin{tabular}{|l|} 
Menciona \\
adapptaçâ
\end{tabular} & \begin{tabular}{|c|c} 
Nắo \\
menciona
\end{tabular} & $\begin{array}{l}\text { Detalhes } \\
\text { (sImNÄ̈) }\end{array}$ \\
\hline \multirow{19}{*}{2009} & \multirow{19}{*}{2000} & Ihtpp://hovocinemaparadiliso. wordpress.com & $x$ & & & & \multirow{18}{*}{18} & & $x$ & \\
\hline & & hitp:///pipocamoderna.mtv.uol.com.br & & & & $x$ & & & $X$ & \\
\hline & & hitp:://cineresesenhas.com & $x$ & & & & & & 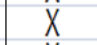 & \\
\hline & & hittp://luww.cineweb.com.br & $x$ & & & & & & $X$ & \\
\hline & & hhitp:I/lcinema.cineclick.uol.com.br & & & & $x$ & & & $x$ & \\
\hline & & hhtp://www.cinepop.com.borl & $x$ & & & & & & $\dot{x}$ & \\
\hline & & hittp://cinema.uol.com.br & & & & $x$ & & & $\dot{x}$ & \\
\hline & & hitp:l/lg1.globo.com & & & & $x$ & & & $X$ & \\
\hline & & hittp:/Vueja.abill.com.br & & & & $x$ & & & $X$ & \\
\hline & & hitp: / /www.omelete.com.br & & & & $x$ & & & $\hat{X}$ & \\
\hline & & hitp: //www.new.dinita-se. uai.com.br & & & & $x$ & & & $X$ & \\
\hline & & hitp: //www.sergito com.br & & & $x$ & & & & $x$ & \\
\hline & & hitp://sergiohpg.wordpress.com & $X(B \log )$ & & & & & $x$ & & NÄOO \\
\hline & & hitp://hww.lixeiradourada.com & & & & $x$ & & & $X$ & \\
\hline & & hitp: /lumw.porraman.com & & & $x$ & & & & $X$ & \\
\hline & & hitp://linelupinha.blogspot.com & $x$ & & & & & & X & \\
\hline & & hitp://receioderemorso. wordpress.com & & & $x$ & & & & $X$ & \\
\hline & & hittp://hww.cineplayers. com & & & & $x$ & & & $X$ & \\
\hline & & & 6 & 0 & 3 & 9 & $x$ & & 17 & \\
\hline
\end{tabular}

No caso do filme $O$ contador de histórias, foram coletadas 18 críticas. seis de sites especializados em cinema, três de sites não especializados e nove de sites de revistas. Apenas uma das críticas mencionou o fato de se tratar de uma adaptação (crítica de site não especializado), e, contudo, meramente aludiu à adaptação do filme. 
ALVES,S.; ANCHIETA, A.; FRASÃO, M. Interfaces, ressignificações e crítica da adaptação da literatura para o cinema

\section{QUINCAS BERRO D'ÁGUA}

\begin{tabular}{|c|c|c|c|c|c|c|c|c|c|c|}
\hline \multirow[b]{2}{*}{$\begin{array}{c}\text { ANO DA } \\
\text { ADAPTAÇÄO }\end{array}$} & \multirow[b]{2}{*}{$\begin{array}{l}\text { ANO DO } \\
\text { LIVRO }\end{array}$} & \multirow[b]{2}{*}{ SITES DAS CRITICAS } & \multicolumn{4}{|c|}{ TIPOS DE FONTE } & \multirow[b]{2}{*}{ TOTAL } & \multicolumn{3}{|c|}{ OBSERVAÇÖES } \\
\hline & & & $\begin{array}{c}\text { Sites e Blogs } \\
\text { especializados em } \\
\text { cinema }\end{array}$ & $\begin{array}{c}\text { Especializados em } \\
\text { literatura }\end{array}$ & $\begin{array}{l}\text { Não- } \\
\text { especializados }\end{array}$ & Revistas & & $\begin{array}{r}\text { Menciona } \\
\text { adaptação }\end{array}$ & $\begin{array}{c}\text { Não } \\
\text { menciona }\end{array}$ & $\begin{array}{l}\text { Detalhes } \\
\text { (SIM/NÄO) }\end{array}$ \\
\hline \multirow{24}{*}{2010} & \multirow{24}{*}{1961} & http://www.omelete.com.br & $x$ & & & & \multirow{24}{*}{25} & $X$ & & NÃO \\
\hline & & http://cinema.cineclick.uol.com.br & $x$ & & & & & $X$ & & NÃO \\
\hline & & http://www. fredburlenocinema.com & & & $x$ & & & $X$ & & NÃO \\
\hline & & http://cinemaeafins.com & $x$ & & & & & $X$ & & NÃO \\
\hline & & http://thebest.blog.br & $\mathrm{x}$ & & & & & $X$ & & NÃO \\
\hline & & http://portalcinema.blogspot.com & $x$ & & & & & $X$ & & SIM \\
\hline & & http.//cinemacomrapadura.com.br & $x$ & & & & & & $X$ & NÃO \\
\hline & & http://www.cinepipocacult.com.br & $x$ & & & & & & $X$ & NÃO \\
\hline & & http://www. cinemanarede.com & $x$ & & & & & & $x$ & NÃO \\
\hline & & http://planetadisney.com.br & $x$ & & & & & & $x$ & NÃO \\
\hline & & http://www. filmesdecinema.com.br & $X$ & & & & & $X$ & & NÃO \\
\hline & & http://vertigop.blogspot.com & & & $x$ & & & & $X$ & NÃO \\
\hline & & http://www.cinema.com.br & $x$ & & & & & $X$ & & SIM \\
\hline & & http://www.cafecompop.com & $x$ & & & & & $X$ & & NÄO \\
\hline & & http://cinema10.com.br & $x$ & & & & & $X$ & & NÃO \\
\hline & & http://universomovie.ning.com & & & $x$ & & & & $X$ & NÃO \\
\hline & & http://www.culturadebolso.org & $x$ & & & & & & $X$ & NÃO \\
\hline & & http://www.cinematotal.com & $x$ & & & & & $X$ & & NÃO \\
\hline & & http://ultimosegundo.ig.com.br & $x$ & & & & & $X$ & & NÃO \\
\hline & & http://www.laboratoriopop.com.br & $x$ & & & & & $X$ & & NÃO \\
\hline & & http://www. parana-online.com.br & $x$ & & & $x$ & & & $X$ & SIM \\
\hline & & http://www.cinemaki.com.br & $x$ & & & & & $X$ & & NÃO \\
\hline & & http://revistastravaganza.com.br & & & & $x$ & & $x$ & & NÃO \\
\hline & & http://www. angelogirotto.com & & & $x$ & & & $x$ & & NÃO \\
\hline & & & 19 & 0 & 4 & 2 & & 16 & 8 & \\
\hline
\end{tabular}

Foram coletadas 25 críticas do filme Quincas Berro D’Água. Entre elas, 19 eram de sites especializados em literatura, quatro de sites não especializados e duas de sites de revistas. 16 críticas mencionaram a adaptação (13 de sites especializados em cinema, duas de sites não especializados e uma de site de revista), no entanto, apenas três, de todas as críticas de sites especializados em cinema, examinaram mais minuciosamente a adaptação.

No total, foram recolhidas 121 críticas dos filmes que compunham o corpus da pesquisa. Desse montante, 54 críticas $(44,62 \%)$ eram de sites especializados em cinema; apenas dois sites (1,65\%) eram especializados em literatura; 42 não eram sites especializados $(34,47 \%)$, como foi o caso de 
ALVES,S.; ANCHIETA, A.; FRASÃO, M. Interfaces, ressignificações e crítica da adaptação da literatura para o cinema

alguns blogs pessoais; 24 críticas $(19,83 \%)$ eram de sites de revistas, como VejaAbril, UOL, Terra, entre outros. Do total de críticas, 52 (42,98\%) mencionaram que o filme era resultante de uma adaptação. Os sites que mencionaram a adaptação se dividiram como consta a seguir: 23 sites (44,23\%) especializados em cinema, nenhum especializado em literatura, 21 críticas $(40,39 \%)$ de sites não especializados e oito críticas $(15,38 \%)$ de revistas. Na maioria dos casos, a crítica realmente apenas mencionava o fato, citando a obra originária. Apenas 14 críticas, o que representa $11,4 \%$ de todas as críticas, apresentaram uma análise mais detalhada da adaptação, e sobre dois filmes (Zuzu Angel e $O$ contador de histórias). Dessas 14 críticas, que se dedicaram mais à adaptação, sete eram de sites especializados em cinema, cinco de sites não especializados e duas de sites de revistas. 0 quadro a seguir ilustra esses dados:

CRITICAS DAS

ADAPTAÇÕES DA LITERATURA PARA O CINEMA

\begin{tabular}{|c|c|c|c|c|c|c|}
\hline \multirow{2}{*}{ FILME } & \multirow{2}{*}{$\begin{array}{c}\text { AMO DA } \\
\text { ADAPTAÇĀOO }\end{array}$} & \multirow{2}{*}{$\begin{array}{l}\text { AMO DO } \\
\text { LNRO }\end{array}$} & \multirow{2}{*}{$\begin{array}{l}\text { TOTAL DE } \\
\text { CRIIICAS }\end{array}$} & \multicolumn{3}{|c|}{ RELATÓRIO PARCIAL } \\
\hline & & & & Menciona adsapta̧̧̧ăo & Năo mencions & Detalhes? (simnão) \\
\hline O CONTADOR DE HISTORIA & 2009 & 2000 & 18 & 1 & 17 & 0 \\
\hline BUDAPESTE & 2009 & 2003 & 10 & 8 & 2 & 3 \\
\hline MUTUM & 2007 & 1964 & 12 & 8 & 4 & 2 \\
\hline ESTÔMAGO & 2007 & 2005 & 19 & 7 & 12 & 1 \\
\hline ZUZU ANGEL & 2006 & 1986 & 14 & 1 & 13 & 0 \\
\hline A MÁQUINA & 2006 & 1999 & 7 & 3 & 4 & 1 \\
\hline QUANTO VALE OUÉ POR QUILO? & 2005 & 1906 & 17 & 8 & 9 & 3 \\
\hline QUINCAS BERRO D'ÁGUA & 2010 & 1961 & 24 & 16 & 8 & 3 \\
\hline
\end{tabular}




\subsection{A crítica - análise qualitativa}

Por conta de uma maior facilidade em acessar a internet, principalmente na última década, o número de sites e blogs aumenta significativamente todos os dias. Isso se reflete na quantidade de blogs de admiradores de cinema e de sites não especializados no assunto. Essa abertura da internet garante um levantamento real do trabalho da crítica, pois em muitos casos, quando não há mais uma referência física do crítico, é possível apenas localizá-lo em páginas virtuais. Além do que o gênero blog, muito popular hoje em dia, foi de grande relevância para a coleta das críticas.

Apesar de todo o acervo disponível na internet, foi muito difícil encontrar sites especializados em literatura que discutissem as questões da adaptação para o cinema. Isso se reflete na quantidade de sites, apenas dois (1,65\% do total de críticas recolhidas na pesquisa) foram encontrados para compor o banco de críticas da pesquisa. Nenhum dos dois sites encontrados discutiu a adaptação, aliás, nem sequer mencionou se tratar de uma adaptação. Isso demonstra um afastamento entre as formas de arte, como se o trabalho de uma arte não pudesse interferir na outra, com uma distinção clara entre a literatura e o filme, ainda que este seja uma adaptação daquela. Vale ressaltar que não consultamos sites de periódicos científicos sobre literatura; mas somente aqueles que se propõem a trazer críticas das obras.

Ao analisar os dados, é possível concluir que, em sua maior parte, as críticas do cinema brasileiro não discutem a questão da adaptação; somente $11,4 \%$ das críticas recolhidas na pesquisa comentaram essa prática. Muitas delas nem mesmo mencionam que o filme é uma adaptação, o que pode representar certo despreparo da crítica para analisar mais profundamente as questões pertinentes ao diálogo literatura/cinema. 
Acreditava-se que a falta de informação seria mais evidente nas críticas dos sites não especializados, no entanto, mesmo em sites especializados em cinema, várias críticas sequer mencionam se tratar de uma adaptação. Ainda que o número de críticas que mencionem a adaptação seja, majoritariamente, de sites especializados em cinema; quando comparadas as porcentagens, percebe-se que os sites não especializados mencionaram mais o fato. Ainda que o percentual de críticas que tenha realmente discutido as questões da adaptação seja relevante, é surpreendente que esse número seja, proporcionalmente, maior em sites não especializados. De certa forma, parece haver uma busca maior por informações por parte dos autores e seguidores destes sites.

0 que se percebe na maior parte das críticas de cinema brasileiro é que há, em parte, incentivo para promover os filmes brasileiros, e, com isso, muitas das críticas acabam restringindo-se à divulgação do filme. Percebese, ainda, por parte da crítica, uma preocupação em apoiar e divulgar o cinema nacional.

Além do incentivo ao cinema brasileiro, foi recorrente a utilização de adjetivos mais voltados para subjetividade nas críticas coletadas. Ocorreram, por exemplo, adjetivações constantes quanto à atuação dos personagens e, em alguns casos, pode estar relacionada à utilização de vários atores com os quais os espectadores se sintam familiarizados. Outra característica repetidamente presente nas críticas foi o teor emotivo em algumas delas, não havendo, portanto, um distanciamento para que o crítico analisasse os elementos do filme, acabando por emitir juízos de valor em sua análise da obra fílmica.

Mesmo o espaço reservado para as críticas de cinema, seja em sites de revistas ou sites especializados, acabam restringindo a análise cinematográfica à mera citação da sinopse do filme, o que comprova se tratar apenas da divulgação dos filmes. Além de apresentarem uma sinopse 
ALVES,S.; ANCHIETA, A.; FRASÃO, M. Interfaces, ressignificações e crítica da adaptação da literatura para o cinema

do filme, algumas delas debatem superficialmente o tema abordado, principalmente se o filme propuser alguma discussão política ou social.

Nas críticas de filmes à margem do circuito comercial, prevaleceram questões sobre contexto social e questionamentos que o filme traz à tona. Por exemplo, em Quanto vale ou é por quilo? Sobressaíram-se as críticas que tratavam da questão das ONG's:

No filme, as personagens representam as classes sociais de onde partem, e por esse motivo, há relativização do que é certo ou errado. Assim, o "fazer o bem" tem significado diferente para as senhoras que ajudam nas ONGs e para o bandido que seqüestra um empresário, fazendo justiça social com as próprias mãos. (GERALDO, 2005. Disponível em <http://www.overmundo.com.br/overblog/analise-dofilme-quanto-vale-ou-e-por-quilo>. ( 27/07/2011)

Constatou-se também que a fama do autor do livro é relevante para a composição da crítica. O filme Budapeste, adaptado do livro do aclamado compositor Chico Buarque, apresentou poucas críticas negativas e destacouse - embora sem falar do processo de tradução - que se tratava de uma adaptação:

Chico Buarque é um nome reverenciado que agora ganha homenagem no cinema. Pois o filme "Budapeste" parece se tratar disso. Mais que a adaptação do livro do compositor brasileiro, o trabalho cinematográfico dirigido por Walter Carvalho é uma demonstração de respeito". (SAÇASHIMA, $2009 . \quad$ Disponível em <http://cinema.uol.com.br/ultnot/2009/05/20/ult4332u1101.htm>. (06/09/2010)

O mesmo ocorreu com a obra Mutum, quando foi objeto de análise de críticos que conhecem a escrita de Guimarães Rosa:

Guimarães Rosa, com maestria, em sua novela Campo Geral, nos apresenta a morte por uma perspectiva sertanista, ingênua e infantil perspectiva, essa, que a diretora Sandra Kogut também utiliza em sua adaptação do livro para o cinema, que recebeu o nome de Mutum, 
ALVES,S.; ANCHIETA, A.; FRASÃO, M. Interfaces, ressignificações e crítica da adaptação da literatura para o cinema

local onde se passa a história. (DonAtel, 2007 Disponível em http://www.jornalirismo.com.br/jornalismo/14/250 Acesso em 08/08/2010)

A questão da fidelidade foi o foco da maioria das críticas que trataram da adaptação. Em Quincas Berro D’água, cerca de $80 \%$ das críticas afirmou que o filme foi bem adaptado, porque seguiu fielmente o enredo do livro, apesar de calcar o tom de comédia à narrativa.

Menos proveitoso para o estudo da adaptação é a repetição de um senso comum de que filme não pode ser tão bom quanto o livro. A crítica de Maurício Stycer, sobre Budapeste, surpreende ao mostrar-se consciente que - processo literatura/cinema se refere a uma tradução, uma reinterpretação, mas mesmo assim conclui sob o ponto de vista da fidelidade, ou melhor, da ideia de que livro é sempre superior:

Como quase sempre acontece, esta adaptação cinematográfica desidrata o romance. Talvez seja a única forma de levar um público maior aos cinemas. E sempre resta a esperança que o filme tenha o efeito de estimular a leitura. (STYCER, 2009. Disponível em <http://colunistas.ig.com.br/mauriciostycer/2009/05/24/tresacrescimosvisiveis-e-uma-revisao-sutil-em-budapeste/>. (13/10/2010)

Para o estudo das adaptações de obras literárias para o cinema, as críticas que não trataram da adaptação, mas que também não se prenderam a juízos de valor e questionamentos sobre fidelidade, mostraram-se mais relevantes. Isso porque passaram a analisar questões mais ligadas à construção fílmica, como direção, fotografia, cenário, atuação dos atores, câmera, etc. Elementos essenciais à composição cinematográfica e necessárias ao estudo da adaptação.

Dentre os sites pesquisados, o Cronópios chama a atenção por se tratar de um site de literatura, assim deixa clara a relação entre cinema e o texto literário: 
Não se trata aqui de dizer simplesmente que o livro é melhor que o filme, como sugere a anedota da traça. Esta é uma questão que nem se coloca dentro de uma crítica responsável, por existir na passagem de uma linguagem para a outra um problema estrutural que de antemão impossibilita a fidedignidade do filme com o universo do livro. (ISZAI, 2009.2 Disponível em <http://www.cronopios.com.br/site/critica. asp?id=4030>.

$(13 / 10 / 2010)$

\section{Conclusão}

Pretendeu-se, com este artigo, apresentar resultados de uma pesquisa que visava verificar como a crítica brasileira de cinema analisava as adaptações feitas no Brasil de obras literárias. Para isso, foram selecionados oito filmes adaptados entre 2005 e 2010.

Verificou-se que a crítica atual transita entre diferentes tipos de critérios e muitas vezes acaba por sucumbir às demandas de mercado.

Pode-se concluir, portanto, que, apesar de as críticas não terem comparado a adaptação à obra escrita apenas sob o critério da fidelidade, elas demonstram pouca preocupação com a adaptação. Nota-se que não houve um aprofundamento teórico nas questões concernentes à adaptação por parte das críticas, e ainda, das que citaram o fato, a maioria foi superficial. Foi dada ênfase a aspectos mais subjetivos e que coubessem juízos de valor, além de se aterem à mera reprodução da sinopse do filme. Observa-se, assim, que as críticas, mesmo as advindas de sites especializados em cinema, não estão singularizando as questões referentes a filmes adaptados.

Os resultados obtidos com a pesquisa e apresentados aqui são uma amostra de como a crítica brasileira (especializada ou não) encara a adaptação da literatura para o cinema, e não esgota a problemática. Esperase, porém, poder contribuir para uma melhor atuação da crítica brasileira 
ALVES,S.; ANCHIETA, A.; FRASÃO, M. Interfaces, ressignificações e crítica da adaptação da literatura para o cinema

quanto ao cinema de adaptação no que concerne à observação do caráter intersemiótico desta prática, além das implicações geradas pelas ressignificações propostas. 


\section{Referências Bibliográficas}

Aumont et al. A estética do Filme. tradução Marina Appenzeller. São Paulo. Papirus, 1995.

BAKER, Mona. (ed.). Routledge Encyclopedia of Translation Studies. London/ New York: Routledge, 2005.

BASTOS, Hermenegildo. Que pai contra que mãe? A questão do ponto de vista em um conto de Machado de Assis. Disponível em: <www. manifestabrasil.pro.br/index.html>. (05/07/2010).

BRANIGAN, Edward. O plano ponto de vista. In Teoria contemporânea do Cinema, v.2. São Paulo: Senac, 2005.

CATTRYSSE, Patrick. Audiovisual Translation and New Media. New York: ABS, 1997.

Cintrão, H. P. ; ZavagliA, A. . Domínios culturais e função poética como condicionantes da adaptação dentro da tradução: reflexões sobre o conceito de "adaptação". In: XI Encontro Regional da ABRALIC 2007, 2007, São Paulo. Anais do XI Encontro Regional da ABRALIC 2007, 2007. p. 1-11.

DonAdelli, João Daniel. Mutum, o sentido da vida que a morte dá. 2007. Disponível em: <http://www.jornalirismo.com.br/jornalismo/14/250> (08/08/2010).

Geraldo, Natália. Crítica do filme Quanto vale ou é por quilo? 2005. Disponível em <http://www.overmundo.com.br/overblog/analise-dofilme-quanto-vale-ou-e-por-quilo>. (Acesso: 27/07/2011).

HALL, S. A identidade cultural na pós-modernidade. Tradução de Tomaz Tadeu da Silva e Guacira Lopes Louro. Rio de Janeiro: DP\&A, 1998.

HeSSEL, Marcelo. Crítica: Zuzu Angel é longa-metragem de diálogos filmados. $2006 . \quad$ Disponível em <http://www.vermelho.org.br/noticia.php?id_noticia=5900\&id_secao= $11>(15 / 06 / 2011)$.

ISZAY, Felipe. Budapeste - o filme. 2010. Disponível em: <http:/ / www.cronopios. com.br/site/critica. asp?id=4030>.

(13/10/2010).

LEFEVERE, André. Translation, rewriting \& the manipulation of literary fame. London and New York: Routledge, 1992.

LUSVARGHI, L., Sobre as relações entre cinema nacional e discurso jornalístico em "Quanto vale ou é por quilo?". in:http://www.mnemocine.com.br/cinema/crit/llusvarghi.htm. $(15 / 08 / 2010)$. 
PLAZA, Julio. Tradução Intersemiótica. SP: Perspectiva, 1987.

SAÇASHIMA, Edilson. Budapeste provoca desorientação ao propor múltiplos sentidos. 2009.2 Disponível em: <http://cinema.uol.com.br/ultnot/2009/05/20/ult4332u1101.jhtm>. (06/09/2010).

STAM, Robert. Beyond Fidelity: the dialogicis of adaptation in: NAREMORE, James. Film Adaptation. Rugters University Press: 2000. 54 -78.

SILVA, Marcel Vieira Barreto. O olhar embaciado de Miguilim: Mutum (2007, dir. Sandra Kogut) e as estratégias cinematográficas de representação do narrador com onisciência seletiva. Anais do XI Congresso Internacional da Associação Brasileira de Literatura Comparada, 2008. s.p.

STYCER, Maurício. Três acréscimos visíveis e uma revisão sutil. 2009. Disponível em: http://colunistas.ig.com.br/mauriciostycer/2009/05/24/tresacrescimos-visiveis-e-umarevisao-sutil-em-budapeste.

Acesso: $13 / 10 / 2010$

XAVIER, I. Do texto ao filme: a trama, a cena e a construção do olhar no cinema. In PELLEGRINI, T. (et alli). Literatura, cinema, televisão. São Paulo: Senac / Itaú Cultural, 2003.

\section{Corpus Literário}

SILVESTRE, L. Pólvora, gorgonzola \& alecrim. São Paulo: Jaboticaba, 2005.

Ramos, R.C. O contador de histórias. Belo Horizonte: Leitura, 2000.

FalCão, Adriana. A máquina. São Paulo: Objetiva, 2005.

BuARque, Chico. Budapeste. São Paulo: Companhia das Letras, 2000.

VALI, Virginia. Eu, Zuzu Angel, procuro meu filho. Rio de Janeiro: Villa Rica Editora, 1986.

MACHADO DE AssIS, Joaquim Maria. Pai contra Mãe. In Obra completa. Rio de Janeiro: Nova Aguilar, 1997 [1906].

RosA, João Guimarães. Manuelzão e Miguilim. Rio de Janeiro: Nova Fronteira, 2001 [1956].

AMADO, Jorge. A morte e a morte de Quincas Berro D'água. São Paulo: Cia da Letras, 2008. [1959] 
ALVES,S.; ANCHIETA, A.; FRASÃO, M. Interfaces, ressignificações e crítica da adaptação da literatura para o cinema

\section{Filmografia}

A MÁQUINA (2006). Direção: João Falcão. Roteiro: João Falcão e Adriana Falcão. Produção: Diller Trindade, Tereza Gonzales, Guel Arraes. Elenco: Paulo Autran, Gustavo Falcão, Mariana Ximenes, Vladimir Britcha, Wagner Moura e outros. Duração: 90min.

BUDAPESTE (2009). Direção: Walter Carvalho. Roteiro: Rita Buzzar, baseado em livro de Chico Buarque. Estúdio: Nexus Cinema / Eurofilm. Distribuidora: Imagem Filmes. Produção: Rita Buzzar. Elenco: Leonardo Medeiros, Giovanna Antonelli , Gabriella Hámori , Paola Oliveira , Débora Nascimento. Duração: 113 min.

MUTUM (2007). Direção: Sandra Kogut. Roteiro: Ana Luiza Martins Costa e Sandra Kogut. Produção: Flávio R. Tambellini, Laurent Lavolé, Isabelle Pragier. Intérpretes: Thiago da Silva Mariz, Walisson Felipe Leal Barroso, João Miguel, Isadora Fernandes, Rômulo Braga e outros. Duração: 95 min.

O CONTADOR de Histórias (2009). Direção: Luiz Vilaça. Roteiro: Produção: Elenco: Duração: Baseado na obra homônima infanto-juvenil de Roberto Carlos Ramos.

QuANTo VAle ou É POR QUILo? (2005) Direção: Sérgio Bianchi. Produção: Patrick Leblanc. Roteiro: Sérgio Bianchi e Eduardo Benaim. Elenco: Ana Carbatti, Herson Capri, Marília Pera, Claudia Mello, Lázaro Ramos e outros.

QUINCAS Berro D‘Água (2010). Direção: Sérgio Machado. Produção: Mauricio Andrade Ramos e Walter Salles. Roteiro: Sérgio Machado. Elenco: Paulo José, Luis Mira, Frank Menezes, Flavio Bauraqui, Irandhir Santos, Marieta Severo, Mariana Ximenes, Vladmir Britcha, Walderez De Barros, Milton Gonçalves, Othon Bastos.

Zuzu Angel (2006). Direção: Sérgio Rezende. Roteiro: Sérgio Rezende e Marcos Bernstein. Elenco: Patrícia Pillar, Daniel de Oliveira, Alexandre Borges, Leandra leal, Luana Piovani, Elke Maravilha e outros. Duração: $110 \mathrm{~min}$. 